\title{
Clitoral Cyst Complicating Neonatal Female Circumcision in a 6 Years Old Child: A Management Plan to Delay Surgical Excision Until Puberty
}

\author{
Anthony Jude Edeh ${ }^{1 *}$, Chijioke Chinedu Anekpo ${ }^{2}$, Balantine Ugochukwu Eze ${ }^{3}$ and Kevin \\ Emeka Chukwubuike ${ }^{4}$ \\ ${ }^{1}$ Department of Surgery College of Medicine, Enugu State University of Technology Teaching Hospital, Nigeria \\ ${ }^{2}$ Consultant ENT Surgeon, Nigeria \\ ${ }^{3}$ Consultant Urology Surgeon, Nigeria \\ ${ }^{4}$ Consultant Paediatric Surgeon, Nigeria
}

*Corresponding author: Anthony Jude Edeh, Department of Surgery College of Medicine, Enugu State University of Technology Teaching Hospital, Enugu, Nigeria.

To Cite This Article: Anthony Jude Edeh. Clitoral Cyst Complicating Neonatal Female Circumcision in a 6 Years Old Child: A Management Plan to Delay Surgical Excision Until Puberty. Am J Biomed Sci \& Res. 2019 - 4(4). AJBSR.MS.ID.000811. DOI: 10.34297/AJBSR.2019.04.000811

Received: July 24, 2019 | Published: August 06, 2019

\begin{abstract}
Among many traditional African societies, including the Ibos of south eastern Nigeria, ritual circumcision has a strong irrational bias and many parents continue to believe in old myths or conjure up new ones to justify this practice. Despite the implementation of laws prohibiting female genital mutilation/cutting (FGM/C), this practice is still performed on nearly 2-3 million women annually [1,2]. We report a case of an unfortunate 6-year-old child who had neonatal ritual circumcision in Enugu, Nigeria. This was complicated by a small clitoral cyst which is asymptomatic but worries the parents. To prevent further physical and psychological trauma to this child we advised delay of excision surgery until puberty unless the cyst becomes complicated.
\end{abstract}

Keywords: Methionine Enkephalin; B-Endorphin; Natural Killer Cells; Naloxone; Human Limphocyte Membranes; Na+ Ion; GTP; Displacement Assays

\section{Introduction}

The practice of female circumcision is still prevalent in about 30 African [3] countries and it is estimated that over 200 million females, including young girls and infants now suffer the effects of this debilitating surgery. The procedure changes normal female genital functionality and because of the nature of the procedure, its outcomes and the permanent damage/disability associated, it is termed as "Female Genital Mutilation/Cutting" (FGM/C) [4]. FG$\mathrm{M} / \mathrm{C}$ includes all procedures that involve intentional removal (either partial or total) of external female genitalia for non-medical reasons and without health benefits [5].

The WHO/UNICEF/UNFPA (World Health Organization/United Nations International Children's Emergency Fund/United Nations Population Fund) joint statement classifies FGM into four types: Clitoridectomy (type 1), excision of clitoris and labia minora (type II), excision of external genitalia with iatrogenic labial fusion- in tubation (type III); and type IV, which describes all other harmful procedures to the female external genital tissue, such as pricking and cauterizing [6].

Clitoral cysts, as part of vulva cyst, which follow FGM is acquired when there is surgical implantation of epidermal tissue or occlusion of a pilo-sebacceous unit. They usually grow very slowly and with few symptoms but could reach a considerable size with time and could be complicated usually by infection $[7,8]$. The treatment is surgical excision with good results at least in adult $[9,10]$.

\section{Case Report}

A four-year-old female child was brought to our clinic by her father because mother has noticed a small, movable swelling in the vulva for upwards of one month. The swelling appears to remain the same and does not give the child any symptoms, but the parents wanted to be advised on its nature. 
She was circumcised by a traditional birth attendant on the 8th day of birth and the procedure apparently healed well. She is the first child of the parents who have two other male children who were also circumcised. The patents are graduates and were themselves circumcised. Physical examination revealed a healthy-looking child who is in no obvious distress with a weight of $15 \mathrm{~kg}$. There was a $2.5 \mathrm{~cm} \times 1.5 \mathrm{~cm}$, cystic and very mobile mass in the region of the clitoris in circumcised external genitalia. We made a clinical diagnosis of epidermal inclusion cyst complicating neonatal circumcision. We counseled the parents on need to delay surgical excision until when she is passed puberty to prevent further physical and possible psychological trauma to the child. However, parents must adhere strictly to regular follow-ups of one to two times annually and they consented (Figure 1 \& Figure 2).

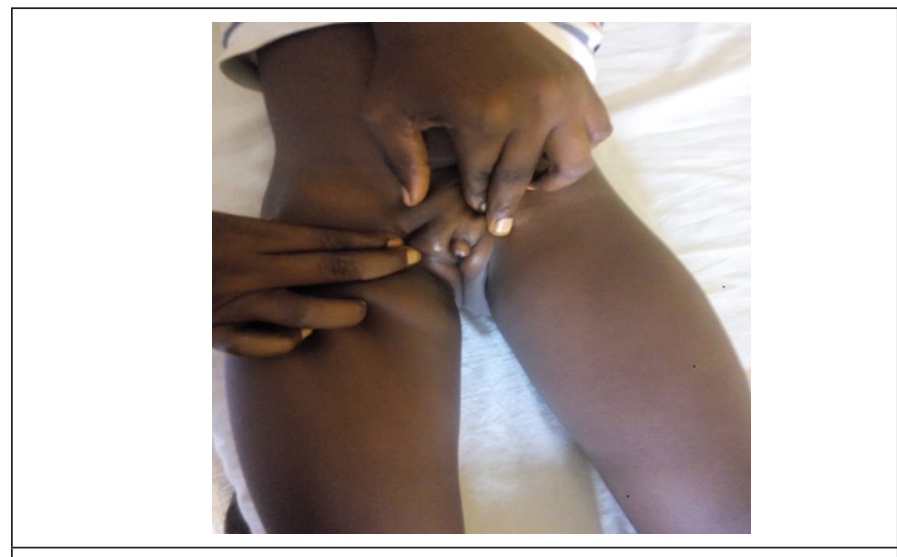

Figure 1: Clitoral cysts which is asymptomatic.

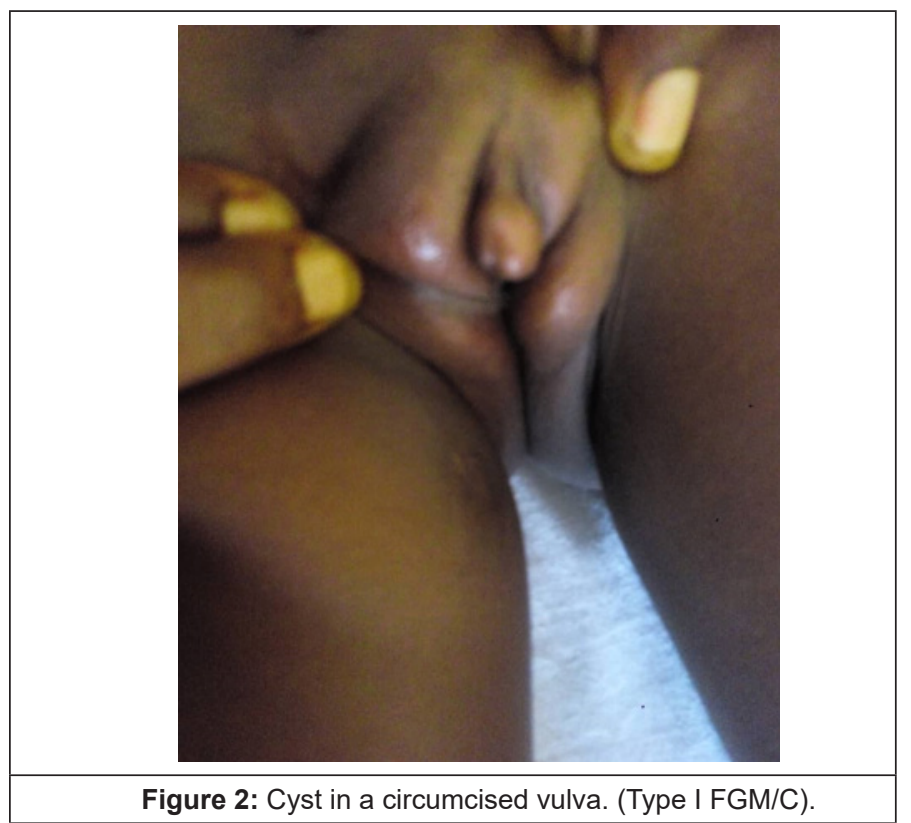

\section{Discussion}

The parents of this child are well educated. They are aware that ritual female circumcision is no longer accepted by all but believe that it helps to induce chastity especially in this age of unrestricted exposure of children to promiscuous information. This belief is strengthened by the perceived consequences should there be an adolescent pregnancy: unsafe abortions, loss of education, early marriage or children out of marriage. Other reasons for embracing circumcision include social acceptance, the safeguard of virginity before marriage, the promotion of marriageability $[5,10]$ rite of passage to adulthood, as part of history or cultural tradition of the specific ethic group [5]. Traditional medical practices and beliefs enjoy a lot of patronage in Nigeria and across various educational and social strata [11]. These are commonest in bone setting, and traditional birth attendants who incidentally are the ritual circumcisers.

Vulva cysts are among the delayed complications of FGM/C. The cyst may form as consequences of those who performed the circumcision. Circumcisers may be skilled in traditional medicine, but their lack of training in surgery, their poor equipment and the fact that the girl may struggle, all suggest that is difficult to be precise in an excision [12]. In many series reported, they grow slowly and do not cause significant symptomatology until after puberty 8,9 and that may be why most excisional surgeries quoted in literature are in adults $[8,9,13-15]$. This may be related to the effects of estrogen on female genital organs which increase significantly only from puberty [16]. We advised delay of surgery until adulthood unless complicated by rapid growth, or signs of infection. We believe this will save this child further physical trauma of surgery and the dangers of general anaesthesia and also prevent future psychosomatic consequences of any such procedure.

\section{Conclusion}

In African, FGM/C is still a deeply entrenched social norm and its eradication appears slow and difficult. In this regard continued advocacy, legal frameworks and measures to address the underlying sociocultural traditions and problems (sex education, family planning and legalized abortion) will eventually abolish this practice.

\section{References}

1. Gulteken IB, Altinboga O, Riza Dur, Kara OF, Kucukozkan T (2016) Surgical reconstruction in female genital mutilation. Turk J Urol 42(2): 111114.

2. Buggio L, Facchin F, Chiappa L, Barbara G, Brambilla M, et al. (2019) Psychosexual Consequences of Female Genital Mutilation and the Impact of Reconstructive Surgery: A Narrative Review. Health Equity 3(1): 36-46.

3. (2008) Eliminating female genital mutilation. An Interagency Statement, World Health Organisation, Geneva, USA.

4. (2018) Female genital mutilation.

5. (2016) WHO guidelines on the management of health complications from female genital mutilation.

6. Berg RC, Taraldsen S, Said MA, Srbge IK, Vangen S (2017) The effectiveness of surgical interrentions for women with FGM/C: G systemtic review. BJOG 125(3): 278-287.

7. Berg RC, Underland V, Odgaard Jensen J, Fretheim A, Vist GR (2014) Effects of Female genital cutting on physical health outcomes: a systematic review and neta-analysis. BMJ Open 4(11): e006316. 
8. Edeh AJ, Okezie CJ, Ohayi RS, Okenwa OW, Nwangwu CC (2019) A huge epidermal inclusion cyst of the vulva complicating neonatal female circumcision. Indian J Case Reports 5(2).

9. Amu OC, Udeh EI, Ugochukwu AI, Madu C, Nzegwu MA (2012) A case of Vulval Swelling Secondary to female circumcision posing a diagnostic dilemma. International Journal of Surgery Case Reports 3(9): 431-434.

10. Megafu U (1983) Female ritual circumcision on Africa: an investigation of the presumed benefits among Ibos of Nigeria. East Africa Medical J 60(11): 793-800.

11. Thanni LOA (2000) Factors influencing patronage of traditional bone setters. West Africa J Medical 19(3) 220-224.

12. Horowitz C, Jackson J (1997) Female Circumcision: African women confront American Medicine. Journal of General internal mediate 12(8): 491-499.
13. Hawly GM, Objeda VI (1995) Epidermal inclusion cysts of the clitoris as a complication of female circumcision and pharonic infibulations. Central Africa of Medical 41(1): 22-24.

14. Asaute A, Omurtay K, Roberts C (2010) Epidermal inclusion cyst of the clitoris 30 years after female genital mutilation: Fertility and sterility 94(3): 1097. e1-e3.

15. Celik N, Yalcin S, Gucer S (2011) Citoral epidermoid cyst secondary to blunt Erauma in a 9-year old-child. The Turkish Journal of Pediatrics 53(1): 108-110

16. Senturk S, Ustuner P, Balik G, Kagitci M, Ural U M, et al. (2014) Labial Adhesion with Acute Urinary Refention Secondary to Vagititis. Case Reports in Obstretrics and Gynaecology p.3. 